\title{
Effects of salivary protein flow and indigenous microorganisms on initial colonization of Candida albicans in an in vivo model
}

\author{
Norihiko Kanaguchi ${ }^{1,3}$, Naoki Narisawa ${ }^{3}$, Tatsuro Ito ${ }^{2,3}$, Yosuke Kinoshita ${ }^{1,3}$, Yasuka Kusumoto ${ }^{1,3}$,
} Osamu Shinozuka ${ }^{1}$ and Hidenobu Senpuku ${ }^{3^{*}}$

\begin{abstract}
Background: Candida albicans is a dimorphic fungus that is part of the commensal microbial flora of the oral cavity. When the host immune defenses are impaired or when the normal microbial flora is disturbed, C. albicans triggers recurrent infections of the oral mucosa and tongue. Recently, we produced NOD/SCID.e2f1 ${ }^{-1-}$ mice that show hyposalivation, decrease of salivary protein flow, lack IgA and IgG in saliva, and have decreased NK cells. Our objective was to characterize C. albicans infection and biofilm formation in mice.

Methods: NOD/SCID.e2 $\mathrm{ft}^{-/-}$mice were used as an animal model for C. albicans infection. C. albicans yeast and hyphal forms solutions were introduced in the oral cavity after disinfection by Chlorhexidine.

Results: The numbers of $C$. albicans colonized and decreased in a time-dependent manner in NOD/SCID.e2f1 $1^{+/+}$ after inoculation. However, the colonization levels were higher in NOD/SCID.e2 $f 1^{+/+}$than NOD/SCID.e2 $f 1^{-1-}$ mice. In the mice fed $1 \%$ sucrose water before inoculation, C. albicans sample was highly contaminated by indigenous microorganisms in the oral cavity; and was not in the mice fed no sucrose water. The colonization of C. albicans was not influenced by the contamination of indigenous microorganisms. The hyphal form of $C$. albicans restricted the restoration of indigenous microorganisms. The decreased saliva in NOD/SCID.e2 $21^{-/-}$did not increase the colonization of $C$. albicans in comparison to $\mathrm{NOD} / \mathrm{SCID} \cdot e 2 \mathrm{fi}^{+/+}$mice. We suggest that the receptor in saliva to C. albicans may not be sufficiently provided in the oral cavity of NOD/SCID.e2 $\mathrm{f1}^{-1-}$ mice.
\end{abstract}

Conclusion: The saliva protein flow may be very important for C. albicans initial colonization, where the indigenous microorganisms do not affect colonization in the oral cavity.

Keywords: Candida albicans, NOD/SCID.e2f1 mice, Saliva, Colonization, Sucrose

\section{Background}

Candida spp. are human commensals commonly colonizing human mucosal surfaces and can participate in biofilm formation on mucosal and cutaneous surfaces as well as on device surfaces, e.g., dentures, venous catheters, and urinary catheters [1-7]. However, under certain conditions, the fungus causes a variety of infections from mild mucosal infections to lifethreatening invasive candidiasis [8]. Many manifestations of candidiasis are associated with the formation

\footnotetext{
* Correspondence: hsenpuku@nih.go.jp

${ }^{3}$ Department of Bacteriology, National Institute of Infectious Diseases, 1-23-1 Toyama, Shinjuku-ku, Tokyo 162-8640, Japan

Full list of author information is available at the end of the article
}

of biofilms on host tissues (e.g., oral thrush) and on indwelling medical devices (central venous catheterassociated candidemia) [9]. A clinically significant characteristic of microbial biofilms is their enhanced resistance to antimicrobial drug therapies [10-12].

Candida albicans is commensal on human mucosal surfaces and is one of the most important nosocomial infections of humans. C. albicans is the most common cause of various forms of candidiasis [13]. Under conditions of immune dysfunction, colonizing $C$. albicans can become an opportunistic pathogen causing recurrent mucosal infections of the oral cavity and vagina in immunecompromised hosts such as the elderly and HIV-positive patients $[14,15]$. C. albicans is a pleiomorphic fungus

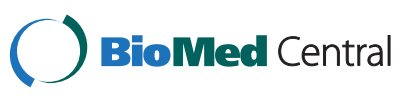


having the ability to transition between cellular yeast and filamentous forms essential for virulence; therefore filamentous forms constitute a central component in C. albicans pathogenesis. Various models have been established to study candidiasis, including Candida-epithelial cell interactions using immortalized human epithelial cell lines in tissue culture [16-18] where C. albicans adheres to the epithelial cells of the oral mucosa and also invades these cells. Invasion into the epithelial cell limit of the oral mucosa is characteristic of both human and experimental animal models of oropharygeal candidiasis [19-22].

A recent investigation developed NOD/SCID background E2F-1 deficient mice (NOD/SCID.e $2 f 1^{-/-}$) (T and $\mathrm{B}$ cells do not develop where the E2F-1 function loss in the NOD/SCID background mice do not have an autoreactive response) [23]. The NOD/SCID.e $2 f 1^{-/-}$mice have decreased saliva volume, lack sIgA and IgG in the saliva, as compared with NOD.e $2 f 1^{+/+}$mice. This mouse have decreased NK cells as compared with SCID mice and may be a useful animal model for studying oral infection, colonization, and biofilm formation. Further, human tissue grafts can be used in this mouse. These mice have long survival because they do not develop systemic diseases such as Insulin Dependent Diabetes Mellitus and Sjögren's Syndrome in comparison to the parent strain NOD.e $21^{-/-}$mice. Recently, we found these mice are highly susceptible to dental caries pathogen; Streptococcus mutans colonization when NOD/SCID.e $2 f 1^{-1-}$ mice are pre-treated with human saliva or sIgA using a low concentration (1\%) sucrose supplement; $S$. mutans biofilm formation occurred when the mice were supplied $1 \%$ sucrose water and a non-sucrose diet [24]. Therefore, these mice may be a useful animal model for $C$. albicans infections in the oral cavity because they have decreased saliva volume and are impaired in immune activity by T, B cells and NK cells.

Mammalian infection models, in particular mouse models, are commonly used to study host-pathogen interaction of human pathogens. Murine models for both superficial and systemic C. albicans infections have been developed and are widely used to study pathogenesis and to determine the virulence of defined $C$. albicans mutants [25,26]. Saliva includes various anti-microbial agents and is likely to play important roles in resistance to infection by $C$. albicans in the oral cavity. Immune-deficient mice such as $\operatorname{Rag}^{-/-}$and CB-17.SCID mice have been used as an infection model for $C$. albicans [27]. However, very little is known about the contribution of saliva in initiation of C. albicans colonization and mucosal infection in the oral cavity using the mouse model. In this study, we investigated the initial colonization of C. albicans in the animal model using NOD/SCID.e $2 f 1^{+/+}$ and NOD/SCID.e $2 f 1^{-/-}$mice.

\section{Methods}

\section{Strains and culture conditions}

The strain used was C. albicans SC5314. C. albicans was incubated for $24 \mathrm{~h}$ at $37^{\circ} \mathrm{C}$ in Yeast Peptone Dextrose (YPD; $2 \%$ Bacto peptone, $2 \%$ dextrose and $1 \%$ yeast extract, Becton Deckinson, Sparks, MD) broth before the beginning of each experiment. The yeast form of $C$. albicans was predominant in culture with YPD overnight; whereas the mycelial form occurred in RPMI1640 (GibcoInvitrogen, Grand Island, NY) with 5\% FBS in overnight culture (Figure 1A). The two cell types were used to inoculate the oral cavity.

\section{Animals}

Heterozygous $\triangle \mathrm{E} 2 \mathrm{~F}-1 \mathrm{NOD} / \mathrm{SCID}$ mice were bred to generate homozygous $\triangle \mathrm{E} 2 \mathrm{~F} 1 \mathrm{NOD} / \mathrm{SCID}$ mice. Three strains of NOD/SCID mice $(e 2 f 1+/+,+/-$ and $-/-)$ were identified using PCR [23]. All mice used were female, 4 months of age, and were maintained in accordance with the guidelines for the Care and Use of Laboratory Animals from the National Institute of Infectious Diseases. Experimental protocols (\#211125) were approved by the National Institute of Infectious Diseases Animal Resource Committee.

\section{Bacterial sampling and colony-forming unit (CFU) estimates}

Bacterial inoculation, sampling, and CFU estimates were performed using procedures and conditions described previously [28-30]. C. albicans yeast and hyphal forms were cultured in YPD and RPMI1640 with 5\% FBS broth overnight and washed twice with sterile phosphatebuffered saline (PBS). In our previous study we demonstrated $S$. mutans colony counts were significantly higher than that of other streptococci (i.e. S. sanguis, S. sobrinus, and $S$. salivarius) in mice that ingested $1 \%$ sucrose in water one day before inoculation [28]. In the same way, $\mathrm{NOD} / \mathrm{SCID} . e 2 \mathrm{f1}^{+/+}$and NOD/SCID.e2 $f 1^{-/-}$mice were also given drinking water containing $1 \%$ sucrose (less than the usual concentration in juice) one day prior to C. albicans inoculation to encourage the early adherence of C. albicans in conditions resembling a natural oral environment. In contrast, drinking water (no sucrose) was used as a control. Chlorhexidine (CHX; $0.2 \%)$ soaked sterile cotton swabs were used to disinfect the oral cavities of the mice including teeth, tongue, and mucosal surfaces. The cavity was immediately washed with sterile PBS. This disinfection was confirmed as few bacterial cells were observed in mice at 30, 60, and 90 min after the inoculation. C. albicans yeast and hyphal forms solutions were introduced to the oral cavities of three females at 4 months of age at a final concentration of $5 \times 10^{9} \mathrm{CFU}$ in $250 \mu \mathrm{l}$ of PBS during a $1 \mathrm{~min}$ period. Following inoculation, samples were collected from the tongue and buccal mucosa with a 


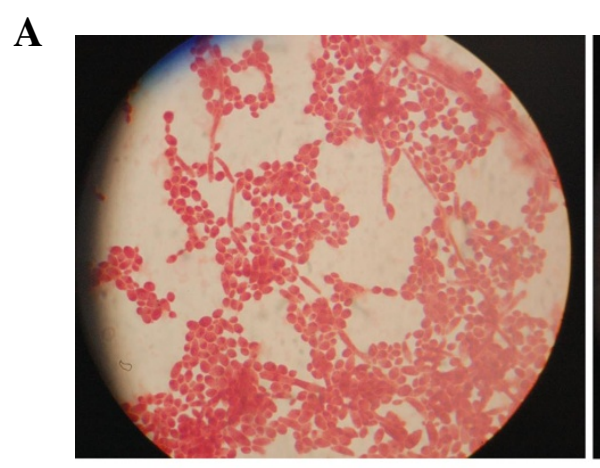

Yeast form

B

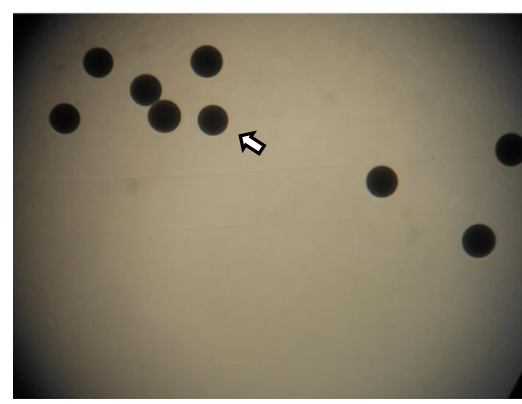

YPD agar
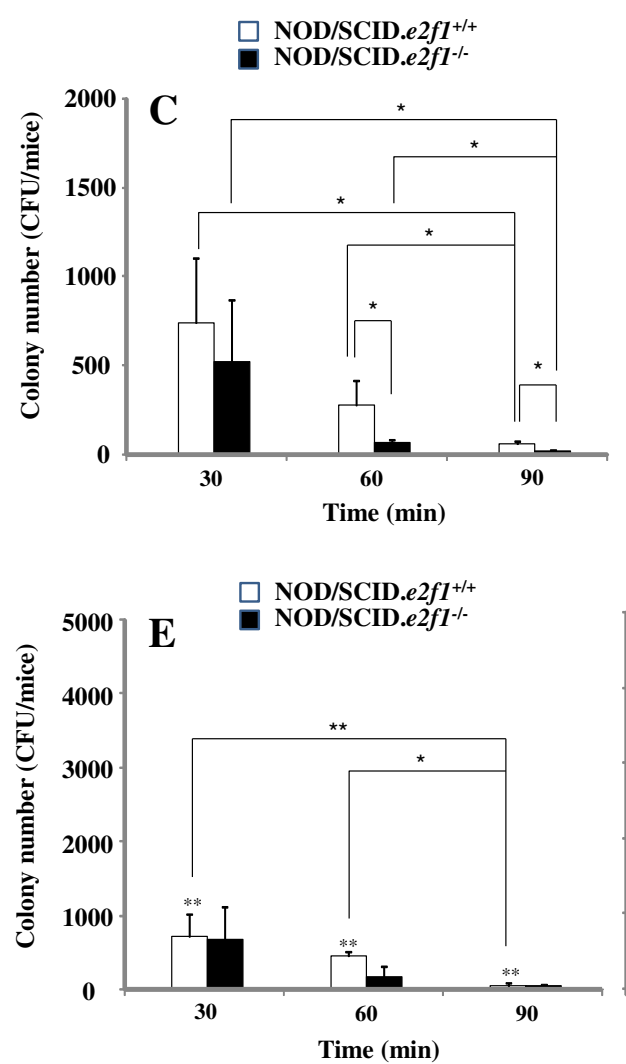

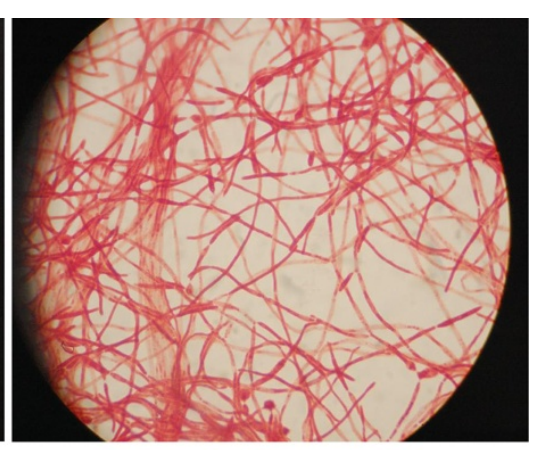

Hyphal form

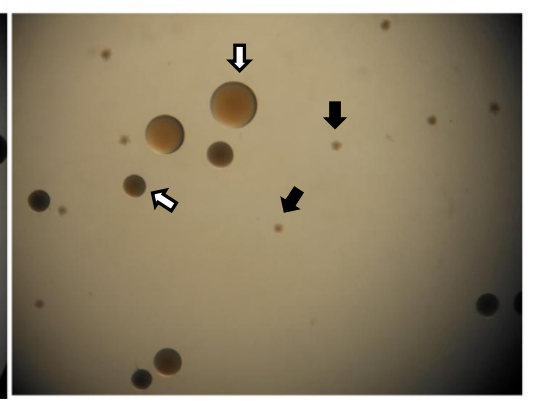

\section{BHI agar}

NOD/SCID.e2f1 $\mathrm{I}^{+++}$

NOD/SCID.e2f1 ${ }^{-/-}$

D
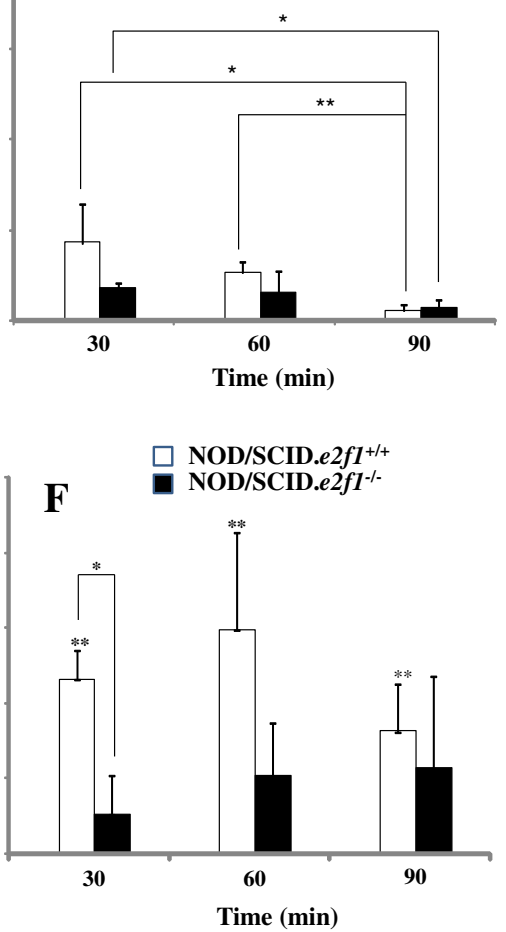

Figure 1 (See legend on next page.) 
(See figure on previous page.)

Figure 1 Observation of $C$. albicans yeast and hyphal forms, and colony numbers after inoculation. C. albicans yeast and hyphal forms were taken pictures in microscope after incubation of them in YPD and RPMI1640 with 5\% FBS (A). The colonization was observed on the YPD agar and $\mathrm{BH}$ agar plates poured swab samples from oral cavity of NOD/SCID.e2f1 $1^{-1-}$ mice fed 1\% sucrose water at 60 min after the inoculation (B). White and black arrow indicated C. albicans and indigenous microorganism colony respectively. These colonies were taken pictures in the stereoscopic microscope. Data were representative in three independent assays. Samples were swabbed from the oral cavities of four 4-month-

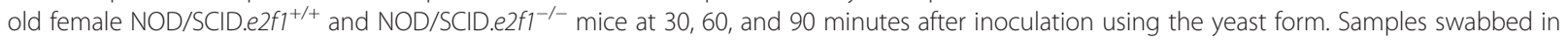
mice fed water $(\mathbf{C})$ or $1 \%$ sucrose water $(\mathbf{D})$ overnight before inoculation were poured on YPD agar. Samples swabbed in mice fed water $(\mathbf{E})$ or $1 \%$ water $(\mathbf{F})$ before inoculation were poured on BHI agar. CFU data were obtained from three independent experiments with four mice from each strain. Values are expressed as the means \pm standard deviations (SDs) of the data. Asterisks show significant differences $\left({ }^{*} P<0.05\right)$ in $C$ and $\mathrm{D}$ and significant differences $(* * 0.05)$ between water $(\mathbf{E})$ and $1 \%$ sucrose water $(\mathbf{F})$ for drinking.

sterile cotton ball at 30, 60 and 90 min after the inoculation and then dipped in $2 \mathrm{ml}$ of PBS. The samples in sterile PBS were sonicated using ultrasonic dispersion (power output, $60 \mathrm{~W}$ ) for $10 \mathrm{~s}$, and then poured onto YPD agar to determine $C$. albicans colony number and on $\mathrm{BHI}$ agar for $\mathrm{C}$. albicans and indigenous microorganism colony number (Figure 1B). CFUs were determined by counting colonies on the YPD agar after 24 hours and on BHI agar plates after $48 \mathrm{~h}$ using aerobic incubation at $37^{\circ} \mathrm{C}$.

\section{Statistical analysis}

All data were analyzed using the Statistical Package for SPSS for Windows (version 100, Chicago, IL). The Student's t-test was used to compare control data and the data for C. albicans after incubation. * indicate $P$-values less than 0.05 , and $*$ at 0.01 were considered to be significant.

\section{Results}

\section{Effects of decreasing saliva and indigenous oral} microorganisms on the $C$. albicans initial colonization

Saliva is thought to play a significant role in the attachment and colonization of C. albicans on tooth and oral mucosa. We evaluated the effects of different volumes of saliva on C. albicans colonization using NOD/SCID wild type and NOD/SCID.e2f1 $1^{-1-}$ mice. The CFU numbers of C. albicans yeast form colonized in the oral cavity after disinfection by chlorhexidine. C. albicans colonization in both mice were significantly decreased from $30 \mathrm{~min}$ to 90 min after inoculation in NOD/SCID.e $21^{+/+}$mice when they were treated with or without sucrose water (Figure 1C and D). The colonization was also decreased; but these reductions were not significantly different in NOD/SCID.e $2 \mathrm{f1}^{-1-}$ mice as compared to NOD/SCID. $e 21^{+/+}$mice. C. albicans CFU numbers were significantly lower in NOD/SCID.e2 $f 1^{-1-}$ mice than those in NOD/SCID wild type mice fed water after 60 and 90 min post inoculation (Figure 1C). Therefore, decreasing saliva is associated with reduced colonization of $C$. albicans. However, the significant differences between NOD/SCID wild and NOD/SCID.e2 $f 1^{-/-}$mice disappeared by including sucrose in the drinking water
(Figure 1D). YPD was used as a selective medium for $C$. albicans because there was a possibility that some indigenous microorganisms in mice may contaminate the swabbed sample after disinfection by Chlorhexidine. BHI agar plating was also used to confirm contamination levels by indigenous microorganisms. The total number of $C$. albicans and indigenous microorganisms on the BHI agar were similar to those on the YPD plates in the $\mathrm{NOD} / \mathrm{SCID} . e 2 \mathrm{f1}^{+/+}$mice with no-sucrose drinking water and the time-dependent decreasing was also similar in colony numbers in YPD to those in BHI (Figure 1C and Figure 1E). However, the total number of $C$. albicans and indigenous microorganisms increased significantly in the sucrose-water as compared with no-sucrose water in NODSCID.e $2 \mathrm{f1}^{+/+}$mice (Figure $1 \mathrm{E}$ and F). However, there were no significant differences among samples at each sampling time in the drinking of sucrose water. In the case of NOD/SCID.e2f1 $1^{-1-}$ mice, a few indigenous bacteria were increased significantly by adding of sucrose in the drinking water, and the colonization did not show significant differences among sampling times (Figure $1 \mathrm{E}$ and $\mathrm{F}$ ). In contrast, with sucrose in the drinking water, many indigenous microorganisms were found because CFU numbers on BHI were significantly higher than those on YPD using the same sample (Figure 1F). Therefore, sucrose helps time-dependent restoration of indigenous microorganisms after disinfection by chlorhexidine but does not affect increased infection by $C$. albicans. Further, decreasing saliva may not help the colonization of C. albicans or restoration of indigenous bacteria in NOD/SCID.e2 $f 1^{-/-}$mouse system.

\section{Comparison of colonization between yeast and hyphal forms in mouse oral cavity}

In severe infection by $C$. albicans, the hyphal form has very important roles as compared to the yeast form. Therefore we tested oral colonization of the hyphal form compared to the yeast form at $60 \mathrm{~min}$ after inoculation. The colonizations of $C$. albicans were similar in the hyphal and yeast forms in both mice (Figure 2A and B). The colonization of total microorganisms was significantly higher with sucrose drinking water than with nosucrose water in the yeast form, but there was no 

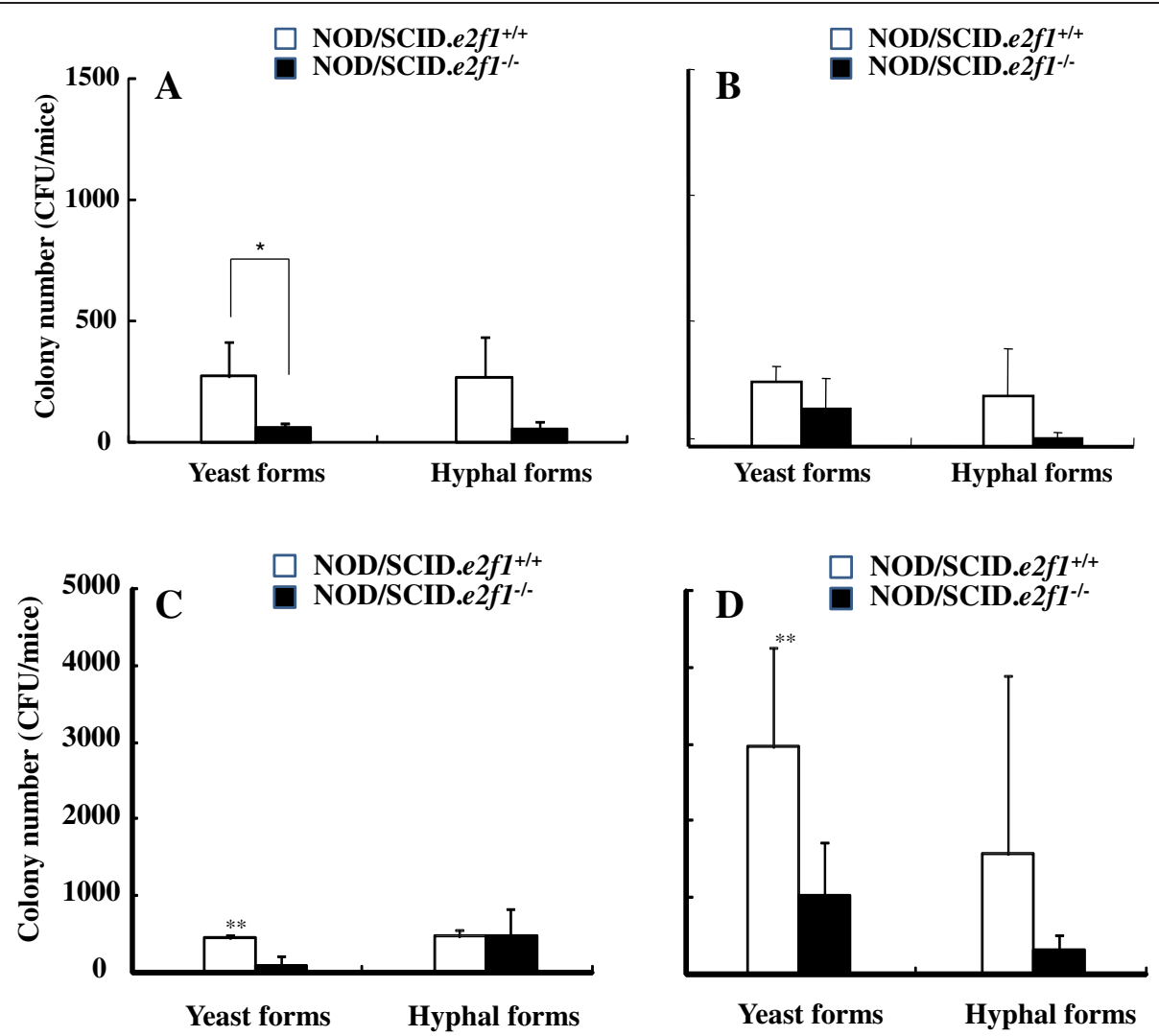

Figure 2 Comparison of the yeast form and hyphal form in colony numbers of C. albicans. Samples swabbed from the oral cavities at 60 minutes after inoculation of the yeast form or hyphal form in four 4-month-old female NOD/SCID.e2 $\mathrm{fl}^{+/+}$and NOD/SCID.e2f1 ${ }^{-/-}$mice fed water (A) or $1 \%$ sucrose water (B) overnight were poured on YPD agar. Other samples in mice fed water (C) or $1 \%$ sucrose water (D) were poured on BHI agar. CFU data were obtained from three independent experiments with four mice from each strain, and values are expressed as the means \pm standard deviations $(\mathrm{SDs})$ of the data. Asterisks show significant differences $(* P<0.05)$ in A and significant differences $(* *<0.05)$ between water (C) and $1 \%$ sucrose water (D) for drinking.

difference in the hyphal form in NOD/SCID.e $2 f 1^{+/+}$mice (Figure $2 \mathrm{C}$ and $\mathrm{D}$ ). The decreased saliva volume in NOD/SCID.e2f1 $1^{-/-}$mice and hyphal form in both mice did not induce the effects of sucrose drinking water on the ratio of the yeast form in NOD/SCID. $e 2 \mathrm{fl}^{+/+}$mice. Therefore, the saliva volume and hyphal form of C. albicans may restrict the restoration of indigenous microorganisms.

\section{Discussion}

The colonization of C. albicans depends on several factors: the acquisition or entry of cells into the oral cavity, the attachment and growth of these cells, the penetration of tissues, and the removal of cells from the oral cavity. In this study, the NOD/SCID.e2 $f 1^{-1-}$ mice with decrease of saliva showed negative colonization of $C$. albicans as compared with NOD/SCID wild type mice. On the tooth surface coated with a salivary pellicle microbial adherence interactions may involve adsorbed saliva molecules. The saliva pellicle increases the adherence of $C$. albicans cells to HA beads [31]. Other investigators previously have shown the presence of serum and salivary pellicles can help C. albicans colonization on acylic strips and denture lining materials $[32,33]$. Therefore, we speculate the NOD/SCID mice produce saliva containing receptors to bind to $C$. albicans and create a salivaexposing environmental mucosal surface in the oral cavity.

In contrast, innate defenses include the epithelial barrier and anti-candidal compounds in saliva such as lysozyme [34], histatins [35], lactoferrin [36], and calprotectin $[37,38]$. Innate host defenses are critical in the maintenance of oral health. Saliva includes lysozome, lactoferrin, and histatins that are thought to be the three major non-immunological antimicrobial proteins to modulate Candida populations in the oral cavity [39]. However, the decreased saliva negatively modulated C. albicans populations in this study. In our previous study, the saliva from NOD/SCID.e $2 \mathrm{fi}^{+/+}$and $e 2 \mathrm{f1}^{-/-}$ mice was characterized in protein concentration $/ \mathrm{ml}$, amylase activities, and protein concentration per $\mathrm{min} / \mathrm{ml}$ [24]. There were no significant differences in protein 
concentration and amylase activity between the mice. The protein concentration per min in $1 \mathrm{ml}$ saliva was significantly lower in NOD/SCID.e2 $21^{-/-}$mice as compared to $\mathrm{NOD} / \mathrm{SCID} . e 2 \mathrm{fl}^{+/+}$mice. Here we did not measure the activities of lysozyme, lactoferrin, or histatins in saliva from $\mathrm{NOD} / \mathrm{SCID} . e 2 \mathrm{f1}^{+/+}$mice and NOD/SCID. $e 2 \mathrm{f1}^{-/-}$mice, but the activities of the innate immunity and the receptors to $C$. albicans attachment may not be sufficiently provided in oral cavity from NOD/SCID.e2 $f 1^{-/-}$as compared with $\mathrm{NOD} / \mathrm{SCID} . e 2 \mathrm{f1}^{+/+}$mice. Mouse salivary proteins are poorly existed in NOD/SCID.e2f1 ${ }^{-/-}$mice. Taken together, mouse saliva works positively for the initial colonization of $C$. albicans rather than protecting by innate immunity, an opposite function to $S$. mutans colonization [24].

The colonization decreased in a time-dependent manner without the effects of saliva volume difference in NOD/SCID. $e 2 \mathrm{f1}^{+/+}$and NOD/SCID.e2f1 ${ }^{-/-}$mice. The colonization may be decreased by washing effects with an appropriate volume of saliva. Moreover, cell-mediated immunity plays an important role in the resistance to mucosal candidiasis $[40,41]$. The mucosal surface provides a protective barrier against bacterial and fungal infections in the oral cavity. The $\beta$-defensins are small cationic amphipathic peptides that exhibit a broad spectrum of activity against gram-positive and gram-negative bacteria and fungal species [42]. NOD/SCID.e $2 f 1^{+/+}$ and NOD/SCID. $22 \mathrm{f1}^{-/-}$mice do not have mature T and $\mathrm{B}$ cells but have a protective barrier with cell-mediated immunity. Therefore, cell-mediated immunity may not be associate with the difference of $C$. albicans colonization between NOD/SCID. $e 2 f 1^{+/+}$and NOD/SCID. $e 2 f 1^{-/-}$mice. The positive function for $C$. albicans in the oral cavity indicates a useful animal model for initial colonization of C. albicans in NOD/SCID wild type mice as compared to NOD/SCID. $e 2 \mathrm{f1}^{-/-}$mice.

Previous report suggested that the indigenous bacterial flora could suppress the extent of colonization of C. albicans by interfering with its ability to attach to mucosal surface in comparison with germ-free rats and conventional rat [43]. This was explained by competing for epithelial receptor sites required for Candida attachment or by enzymatically altering the surfaces of the yeast cells. Our mouse model system using oral inoculation of C. albicans is different from previous report using germ free and conventional rat and indicates better model to explore effects of salivary components and indigenous microorganisms on the colonization under the natural background condition than previous model system. Sucrose works as a substrate for production of glucan by oral streptococci. The drinking of sucrose water before inoculation provides a source of glucan for the restoration of indigenous microorganisms. CHX was uniformly effective against strains of common borne microorganisms. The treatment with CHX disinfected the indigenous microorganism before inoculation in both no-sucrose and sucrose drinking water $[44,45]$. However, the indigenous microorganisms contaminated the sample of C. albicans in the mice fed $1 \%$ sucrose water. The colonization of C. albicans was not affected by restoration of indigenous microorganisms. Therefore, the initial colonization of C. albicans is not affected by later colonization of indigenous microorganisms in the oral cavity. It is suggested that the colonized cells of C. albicans are not removed by the enzymatical or physical effect by indigenous microorganisms.

Yeast-form cells adhere more effectively than hypal cells to endothelial cells under conditions of flow [46]. Although cells locked in the filamentous state also display reduced virulence [47-49], the ability to form hyphae is important for C. albicans to cause disease after dissemination: cells locked in the yeast form remain avirulent until they are permitted to form hyphae, after which, mice succumb to the infection [50]. C. albicans hyphae are impaired in their ability to adhere to the human oral cavity by the bacterium Streptococcus gordonii [51]. To colonize and infect the oral environment, yeast cells must first adhere to host cells and tissues or prosthetic materials within the oral cavity or co-aggregate with the oral microbiota [52-54]. In this study, the hyphae form of $C$. albicans showed similar results as the yeast form but the restoration of the indigenous microorganisms was weaker with the hyphal form than that with the yeast form. This may indicate restriction effects by the hyphal form on the restoration.

We provide here an original new animal model system, which may be a useful model to explore oral initial colonization of $C$. albicans. The salivary protein flow may play important roles in maintaining the commensal behavior of $C$. albicans and becoming an opportunistic pathogen under the immune deficiency condition such as SCID. These mice are required for these investigations to determine several factors that contribute to the susceptibility for candidal infections.

\section{Conclusions}

In conclusion, the saliva protein flow may be very important for C. albicans initial colonization, where the indigenous microorganisms do not affect $C$. albicans initial colonization in the oral cavity.

\section{Competing interests}

The authors declare that they have no competing interests.

\section{Authors' contributions}

NK carried out animal experiments and attend to draft the manuscript. NN helped animal experiments and to draft the manuscript. TI helped to produce mouse. YK helped to maintain and produce mouse. YK participated in the design of the study. OS participated in the design of study and coordination. HS designed the study, carried out production of mouse and described manuscript. All authors read and approved the final manuscript. 


\section{Acknowledgements}

The authors thank Chung Xi for technical support, helpful discussions, and advice. This work was supported in-part by a grant-in-aid for the Development of Scientific Research (19791360, 22791822, and 21390506); and the Ministry of Health, Labor and Welfare (H22 Iryo-Ippan-026). This work was also supported in-part by a Strategic Research Foundation Grant-aided Project for Private Universities from the Ministry of Education, Culture, Sports, Science, and Technology of Japan (MEXT), 2008-2012 (S0801032).

\section{Author details}

${ }^{1}$ Dentistry for Persons with Disabilities, Tokyo Medical \& Dental University, Tokyo, Japan. ${ }^{2}$ Department of Pediatric Dentistry, Nihon University Graduate School of Dentistry at Matsudo, Chiba, Japan. ${ }^{3}$ Department of Bacteriology, National Institute of Infectious Diseases, 1-23-1 Toyama, Shinjuku-ku, Tokyo 162-8640, Japan.

Received: 7 February 2012 Accepted: 23 July 2012

Published: 31 August 2012

\section{References}

1. Douglass $\sqcup$ : Candida biofilms and their role in infection. Trends Microbiol 2003, 11:30-36.

2. Douglass $\sqcup$ : Medical importance of biofilms in Candida infections. Rev Iberoam Micol 2002, 19:139-143.

3. Kumamoto CA: Candida biofilms. Curr Opin Microbiol 2002, 5:608-611.

4. Kawamura-Sato K, Wachino J, Kondo T, Ito H, Arakawa Y: Reduction of disinfectant bactericidal activities in clinically isolated Actinetobacter species in the presence of organic material. J Antimicrob Chemother 2008, 61:568-576.

5. Lopez-Ribot JL, McAtee RK, Perea S, Kirkpatrick WP, Rinalci MG, Petterson TF: Multiple resistance phenotypes of Candida albicans coexist during episodes of oropharyngeal candidiasis in human immunodeficiency virus-infected patients. Antimicrob Agents Chemother 1999, 43:1621-1630.

6. Mukherjee PK, Clandra J: Candida biofilm resistance. Drug Resist Updat 2004, 7:301-309.

7. Ramage G, Wickes BL, Lopez-Ribot JL: Biofilms of Candida albicans and their associated resistance to antifungal agents. Am Clin Lab 2001, 20:42-44.

8. Eggimann P, Garbino J, Pittet D: Epidemiology of Candida species infections in critically ill non-immunosuppressed patients. Lancet Infect Dis 2003, 3:685-702.

9. Bailli GS, Douglas LJ: Matrix polymers of Candida biofilmsand their possible role in biofilm resistance to antifungal agents. J Antimicrob Chemother 2000, 46:397-403.

10. Donlan RM, Costerton JW: Bioiofilms: survival mechanisms of clinically relevant microorganisms. Clin Microbiol Rev 2002, 15:167-193.

11. Kumamoto CA, Vinces MD: Alternative Candida albicans lifestyles: growth on surfaces. Annu Rev Microbiol 2005, 59:113-133.

12. Nett J, Lincoln L, Marchillo K, Massey R, Holoyda K, Hoff B, VanHandel M, Andes D: Putative role of beta-1,3 glucans in Candida albicans biofilm resistance. Antimicrob Agents Chemother 2007, 51:510-520.

13. Richards MJ, Edwards JR, Culver DH, Gaynes RP: Nosocomial infections in coronary care units in the United States. National Nosocomial Infections Surveillance System. Am J Cardiol 1998, 82:789-793.

14. Reichart PA, Philipsen HP, Schmidt-Westhausen A, Samaranayake LP: Pseudomembranous oral candidiasis in HIV infection: ultrastructural findings. J Oral Pathol Med 1995, 24:268-281.

15. de Repentigny $L$, Lewandowski $D$, Jolicoeur P: Immunopathogenesis of oropharyngeal candidiasis in human immunodeficiency virus infection. Clin Microbiol Rev 2004, 17:729-759.

16. Fu Y, Rieg G, Fonzi WA, Belanger PH, Edwards JE, Filler SG: Expression of the Candida albicans gene ALSI in Saccharomyces cerevisiae induces adherence to endothelial cells. Infect Immun 1998, 66:1783-1786.

17. McDonnell GE: Antisepsis, Disinfection, and sterilization; types, action, and resistance. Washington, DC: AZM press; 2007.

18. Sandovsky-Losica H, Chauhan N, Calderone R, Segal E: Gene transcription studies of Candida albicans following infection of HEp2 epithelial cells. Med Mycol 2006, 44:329-334.

19. Cawson RA, Rajasingham KC: Ultrastructural features of the invasive phase of Candida albicans. Br J Dermatol 1972, 87:435-443.

20. Eversole LR, Reichart PA, Ficarra G, Schimidt-Westhausen A, Romagnoli $P$, Pimpinelli N: Oral keratinocyte immune responses in HIV-associated candidiasis. Oral Surg Oral Med Oral Pathol Oral Radiol Endodont 1997, 84:372-380.

21. Kamai Y, Kobota M, Hosokawa T, Fukuoka T, Filler SG: New model of oropharyngeal candidiasis in mice. Antimicrob Agents Chemother 2001, 45:3195-3197

22. Montes LF, Wilbom WH: Ultrastructural features of host-parasite relationship in oral candidiasis. J Bacteriol 1986, 96:1349-1356.

23. Matsui-Inohara $H$, Uematsu H, Narita T, Satoh K, Yonezawa H, Kuroda K Ito T, Yoneda S, Kawarai T, Sugiya H, Watanabe H, Senpuku H: E2F-1deficient NOD/SCID mice developed showing decreased saliva production. Exp Biol Med 2009, 234:1519-1524.

24. Ito T, Maeda T, Senpuku H: Roles of salivary components in Streptococcus mutans colonization in a new animal model using NOD/SCID.e2 $f 1^{-/}$ mice. PLoS One, in press.

25. Naglik JR, Fidel PL Jr, Odds FC: Animal models of mucosal Candida infection. FEMS Microbiol Lett 2008, 283:129-139.

26. de Repentigny L: Animal models in the analysis of Candida hostpathogen interactions. Curr Opin Microbiol 2004, 7:324-329.

27. Pandiyan $\mathrm{P}$, Conti HR, Zheng L, Peterson AC, Mathern DR, Hernández-Santos N, Edgerton M, Gaffen SL, Lenardo MJ: Cell: CD4(+)CD25(+)Foxp3(+) regulatory $T$ cells promote Th17 cells in vitro and enhance host resistance in mouse Candida albicans Th17 cell infection model. Immunity 2011, 34:422-434.

28. Matsumoto N, Salam MA, Watanabe H, Amagasa T, Senpuku H: Role of gene $E 2 f 1$ in susceptibility to bacterial adherence of oral streptococci to tooth surfaces in mice. Oral Microbiol Immunol 2004, 19:270-276.

29. Senpuku H, Matin K, Salam MA, Kurauchi I, Sakurai S, Kawashima M, Murata T, Miyazaki H, Hanada N: Inhibitory effects of MoAbs against a surface protein antigen in real-time adherence in vitro and recolonization in vivo of Streptococcus mutans. Scand J Immunol 2001, 54:109-116.

30. Salam MA, Matsumoto N, Matin K, Tsuha Y, Nakao R, Hanada N, Senpuku H: Clin Diagn Lab Immunol 2004, 11:379-386.

31. Cannon RD, Nand AK, Jenkinson HF: Adherence of Candida albicans to human salivary components adsorbed to hydroxylapatite. Microbiology 1995, 141:213-219.

32. Nikawa $H$, Nishimura $H$, Hamada T, Yamashiro $H$, Samaranayake LP: Effects of modified pellicles on Candida biofilm formation on acrylic surfaces. Mycoses 1999, 42:37-40.

33. Nikawa H, Nishimura H, Makihira S, Hamada T, Sadamori S, Samaranayake LP: Effect of serum concentration on Candida biofilm formation on acrylic surfaces. Mycoses 2000, 43:139-143.

34. Tobgi RS, Samaranayake LP, MacFarlane TW: In vitro susceptibility of Candida species to lysozyme. Oral Microbiol Immunol 1988, 3:35-39.

35. Xu T, Levitz SM, Diamond RD, Oppenheim FG: Anticandidal activity of major human salivary histatins. Infect Immun 1991, 59:2549-2554.

36. Nikawa H, Samaranayake LP, Tenovuo J, Pang KM, Hamada T: The fungicidal effect of human lactoferrin on Candida albicans and Candida krusei. Arch Oral Biol 1993, 38:1057-1063.

37. Müller F, Frøland SS, Brandtzaeg P, Fagerhol MK: Oral candidiasis is associated with low levels of parotid calprotectin in individuals with infection due to human immunodeficiency virus. Clin Infect Dis 1993, 16:301-302

38. Challacombe SJ: Immunologic aspects of oral candidiasis. Oral Surg Oral Med Oral Pathol 1994, 78:202-210.

39. Samaranayake YH, MacFarlane TW, Samaranayake LP, Aitchison TC: The in vitro lysozyme susceptibility of Candida species cultured in sucrose supplemented media. J Nat Prod 1992, 55:1648-1654.

40. Cantorna MT, Balish E: Mucosal and systemic candidiasis in congenitally immunodeficient mice. Infect Immun 1990, 58:1093-1100.

41. Wei XQ, Charles IG, Smith A, Ure J, Feng GJ, Huang FP, Xu D, Muller W Moncada S, Liew FY: Altered immune responses in mice lacking inducible nitric oxide synthase. Nature 1995, 375:408-411.

42. Schutte BC, Mitros JP, Bartlett JA, Walters JD, Jia HP, Welsh MJ, Casavant TL, McCray PB Jr: Discovery of five conserved beta-defensin gene clusters using a computational search strategy. Proc Natl Acad Sci U S A 2002, 99:2129-2133.

43. Liljemark WF, Gibbons RJ: Suppression of Candida albicans by human oral streptococci in gnotobiotic mice. Infect Immun 1973, 8:846-849.

44. Müller $G$, Kramer A: Biocompatibility index of antiseptic agents by parallel assessment of antimicrobial activity and cellular cytotoxicity. J Antimicrobial Chemother 2008, 61:1281-1287. 
45. Sanchez IR, Nusbaum KE, Swaim SF, Hale AS, Henderson RA, McGuire JA: Chlorhexidine diacetate and povidone-iodine cytotoxicity to canine embryonic fibroblasts. Staphylococcus aureus 1988, 17:182-185.

46. Grubb SE, Murdoch C, Sudbery PE, Saville SP, Lopez-Ribot JL, Thornhill MH: Adhesion of Candida albicans to endothelial cells under physiological conditions of flow. Infect Immun 2009, 77:3872-3878.

47. Braun BR, Johnson AD: Control of filament formation in Candida albicans by the transcriptional repressor TUP1. Science 1997, 277:105-109.

48. Braun BR, Head WS, Wang MX, Johnson AD: Identification and characterization of TUP1-regulated genes in Candida albicans. Genetics 2000, 156:31-44

49. Murad AM, Leng P, Straffon M, Wishart J, Macaskill S, MacCallum D, Schnell N, Talibi D, Marechal D, Tekaia F, d'Enfert C, Gaillardin C, Odds FC, Brown AJ: NRG1 represses yeast-hypha morphogenesis and hypha-specific gene expression in Candida albicans. EMBO J 2001 20:4742-4752.

50. Saville SP, Lazzell AL, Monteagudo C, Lopez-Ribot JL: Engineered control of cell morphology in vivo reveals distinct roles for yeast and filamentous forms of Candida albicans during infection. Eukaryot Cell 2003, 2:1053-1060.

51. Silverman RJ, Nobbs AH, Vickerman MM, Barbour ME, Jenkinson HF: Interaction of Candida albicans cell wall Als3 protein with Streptococcus gordonii SspB adhesin promotes development of mixed-species communities. Infect Immun 2010, 78:4644-4652.

52. Cannon RD, Chaffin WL: Oral colonization by Candida albicans. Crit Rev Oral Biol Med 1999, 10:359-383.

53. Jabra-Rizk MA, Falkler WA Jr, Merz WG, Kelley Jl, Baqui AA, Meiller TF: Coaggregation of Candida dubliniensis with Fusobacterium nucleatum. J Clin Microbiol 1999, 37:1464-1468.

54. Chaffin WL, López-Ribot JL, Casanova M, Gozalbo D, Martínez JP: Cell wall and secreted proteins of Candida albicans: identification, function, and expression. Microbiol Mol Biol Rev 1998, 62:130-180.

doi:10.1186/1472-6831-12-36

Cite this article as: Kanaguchi et al:: Effects of salivary protein flow and indigenous microorganisms on initial colonization of Candida albicans in an in vivo model. BMC Oral Health 2012 12:36.

\section{Submit your next manuscript to BioMed Central and take full advantage of:}

- Convenient online submission

- Thorough peer review

- No space constraints or color figure charges

- Immediate publication on acceptance

- Inclusion in PubMed, CAS, Scopus and Google Scholar

- Research which is freely available for redistribution 